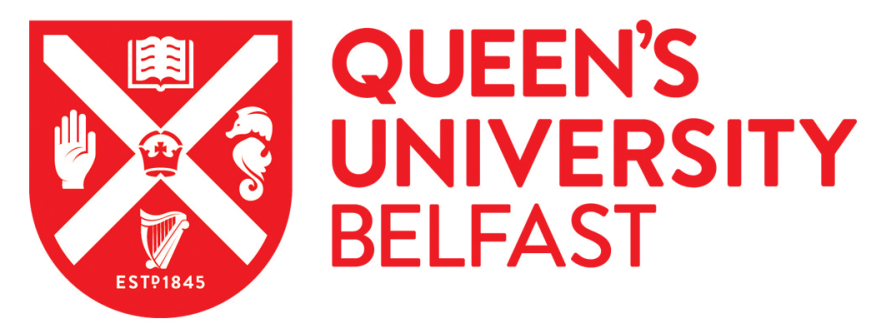

\title{
Comparative feeding rates of native and invasive ascidians
}

Hoxha, T., Crookes, S., Lejeusne, C., Dick, J. T. A., Chang, X., Bouchemousse, S., Cuthbert, R. N., \& Maclsaac, H. J. (2018). Comparative feeding rates of native and invasive ascidians. Marine Pollution Bulletin, 135, 10671071. https://doi.org/10.1016/j.marpolbul.2018.08.039

\section{Published in:}

Marine Pollution Bulletin

\section{Document Version:}

Peer reviewed version

Queen's University Belfast - Research Portal:

Link to publication record in Queen's University Belfast Research Portal

\section{Publisher rights}

(C) 2018 Published by Elsevier Ltd.

This manuscript version is made available under the CC-BY-NC-ND 4.0 license http://creativecommons.org/licenses/by-nc-nd/4.0/,which permits distribution and reproduction for noncommercial purposes, provided the author and source are cited.

\section{General rights}

Copyright for the publications made accessible via the Queen's University Belfast Research Portal is retained by the author(s) and / or other copyright owners and it is a condition of accessing these publications that users recognise and abide by the legal requirements associated with these rights.

Take down policy

The Research Portal is Queen's institutional repository that provides access to Queen's research output. Every effort has been made to ensure that content in the Research Portal does not infringe any person's rights, or applicable UK laws. If you discover content in the Research Portal that you believe breaches copyright or violates any law, please contact openaccess@qub.ac.uk. 


\section{Comparative feeding rates of native and invasive ascidians}

3 Tedi Hoxha $^{1^{*}}$, Steve Crookes ${ }^{1,2^{*}}$, Christophe Lejeusne ${ }^{3}$, Jaimie T.A. Dick ${ }^{4}$, Xuexiu Chang ${ }^{5}$,

$6{ }^{1}$ Great Lakes Institute for Environmental Research, University of Windsor, Windsor, Ontario, N9B 3P4, Canada

$8{ }^{2}$ Biodiversity Institute of Ontario, University of Guelph, Guelph, Ontario, N1G 2W1, Canada

$9 \quad{ }^{3}$ Sorbonne Université, CNRS, UMR 7144 AD2M, Station Biologique de Roscoff, Place Georges Teissier, 29680 Roscoff, France

$11{ }^{4}$ Institute for Global Food Security, School of Biological Sciences, Queen's University Belfast, 12 Belfast, Northern Ireland, BT9 7BL, UK

$13{ }^{5}$ School of Ecology and Environmental Sciences, Yunnan University, Kunming 650091, China

6 Department of Biology, University of Fribourg, Chemin du musée 10, 1700 Fribourg, Switzerland

* Authors contributed equally

Keywords: functional response, invasive species, relative impact, ascidians, nonindigenous species, non-native species

21 Correspondence: hughm@uwindsor.ca, hughm@uwindsor.ca; ph. (+1)519 253-3000 ext. 3754, 


\section{Abstract}

Ascidians have a recent history of species introductions globally, often with strong ecological impacts. Comparisons of per capita effects of invaders and comparable natives are useful to assess such impacts. Here, we explore ingestion rates (IR) and clearance rates (CR) of Ciona intestinalis and Ciona robusta, co-occurring native and non-native ascidians, respectively, from Brittany, France. IR was positively related to food concentration, with the invader responding more strongly to increasing food concentration. CR also differed by species, with the invader demonstrating higher values. C. robusta exhibited a higher functional response (Type I) than did C. intestinalis (Type II). Relative impact measured using seasonal abundance and IR revealed that $C$. robusta has a much greater impact than $C$. intestinalis at all food concentrations tested, though the former has a constrained distribution which limits its regional impact. Nevertheless, when abundant, we expect $C$. robusta to exert a greater impact on algal foods.

\section{Introduction}

Aquatic invasive species (AIS) are increasingly common in both marine and freshwater habitats world-wide owing to a combination of intentional (e.g. stocking) and unintentional (e.g. hull fouling, ballast water) introductions (e.g. Ruiz et al. 2000; Ricciardi 2006). AIS are among the strongest stressors in many aquatic ecosystems (e.g. Clavero and Garcia-Berthou 2005; Allen et al. 2013; Arthington et al. 2016), with a subset of introduced species exerting strong ecological, health and/or economic costs.

Ascidians are primarily sessile organisms with a brief pelagic (lecithotrophic) larval stage. Numerous ascidian species have experienced an increase in global range linked to humanmediated spread and, in some cases, climate warming (e.g. Lambert 2001, 2007; Sorte et al. 
2010; Bock et al. 2011; Zhan et al. 2015; Simkanin et al. 2016; Nydam et al. 2017). In total, Zhan et al. (2015) catalogued 80 species that were recognized as non-native in the habitats in which they were reported. In the Netherlands, non-native ascidians colonized during two major spates, one in 1974-1977, the other in 1991-2004 (Gittenberger 2007). The increase in the number of non-native ascidian species reported in the USA was low but relatively linear between 1850 and 1950, thereafter increasing sharply on both Pacific and Atlantic coasts (Simkanin et al. 2016).

On the English Channel coast of Brittany, France, non-native Ciona robusta (previously Ciona intestinalis type A) co-occurs with C. intestinalis (previously C. intestinalis type B) (Brunetti et al. 2015; Bouchemousse et al. 2016a). While the arrival date of C. robusta is not known, it is believed to have established since the turn of the 21 st century (Bouchemousse et al. 2016a). As the species occupy the same habitats and are filter feeders, they have the potential to compete for settling substrates or for food (Bouchemousse et al. 2017).

Human-mediated range enhancement of ascidians has been effected mainly by fouling on ships, transfer on equipment or as a fellow traveler on aquaculture stock, and by fishery or recreational boats, although there is a small likelihood of transfer in ballast water (see Zhan et al. 2015). As introduced ascidians often adversely affect recipient communities, their spread is cause for concern (see Lambert 2009; Zhan et al. 2015). Identifying which introduced species are likely to produce strong impacts is a daunting challenge owing to the varying nature of the species themselves, the nature of the ecosystems that they are introduced into, and a variety of context-dependencies (Kumschick et al. 2015). Recently, Dick et al. (2014) proposed analyzing comparative functional responses (FR) of introduced species (or those that might be introduced) versus those of comparable native taxa to 
assess whether the former would have high impact. The functional response considers a species' per capita resource consumption as a function of resource availability, and Dick et al.'s (2014) study highlighted that invader FRs typically exceed those of native species. This approach was then extended by combining it with species abundance data to yield a total impact potential for the invader scaled to that of the native species (Dick et al. 2017a).

In this study, we explore the comparative feeding ecology of non-native Ciona robusta and native $C$. intestinalis to determine whether these taxa have similar feeding attributes and expected ecological effects, or whether the general pattern of invader $>$ native that Dick et al. (2014) identified also holds for these very similar ascidians.

\section{Methodology}

2.1 Sampling procedure

Ciona individuals were collected by scraping from pontoons and pillars in Brest, France on $25^{\text {th }}$ September, 2015 and acclimated in the animal husbandry lab $\left(18^{\circ} \mathrm{C}\right)$ at the Roscoff Biological Station, France. Ciona cultures were maintained on Isochrysis affinis galbana algae (issued from the Roscoff Culture Collection (RCC) facility under the reference numbers RCC1349) at concentrations of $15-20 \times 10^{6}$ cells $/ \mathrm{mL}$. Seven experimental food concentration treatments $(1508,3380,5900,12873,29539,51616,133084$ cells $/ \mathrm{mL})$ were determined using a Malassez cell counting chamber. Experimental Ciona individuals were housed in separate cylindrical tanks, each filled with 2 L seawater, totaling seven tanks. Six of the seven tanks contained Ciona individuals, with the remaining one containing only Tisochrysis, thereby serving as a control. Of the six experimental tanks, three contained a single C. intestinalis individual and food, while the other three had a single C. robusta individual and food. Ciona individuals were randomly selected and distinguished morphologically. This design was repeated 
93 twice to produce six replicates for each ascidian species at each algal concentration, with the 94 exception of the treatment with 12783 algal cells $/ \mathrm{mL}$, where time constraints only allowed for 95 three replicates of each species.

2.2 Experimental setup

At the beginning of each trial, individuals were placed upright at the midpoint of each tank, while $10 \mathrm{~mL}$ of concentrated algae suspension was injected into the centre of the tank. The algal suspension was mixed using an air bubbler affixed with plasticine to the side of each tank. Feeding trials were run for $1 \mathrm{hr}$, after which algal cell counts were obtained using flow cytometry, focusing on cells 3.5-6 $\mu \mathrm{m}$ in diameter (Bendif et al. 2013). Three replicate $1.5 \mathrm{~mL}$ samples were collected from the centre of each tank $(2 \mathrm{~cm}$ below the surface) to assess algal concentration, and stored in $1.6 \mathrm{~mL}$ Eppendorf tubes containing $15 \mu \mathrm{L}$ of $25 \%$ glutaraldehyde at $-80^{\circ} \mathrm{C}$ for preservation. Cell densities were then quantified using a Cell Lab Quanta Flow Cytometer (Beckman Coulter, Inc.) at a calibrated flow rate of $30 \mu \mathrm{L} \mathrm{min}{ }^{-1}$, and cell counts were converted to cells/mL. Final and initial algal concentrations in experimental tanks were compared with a correction for controls lacking animals. Following the experiment, the middle gut (from the stomach to the anus) of each individual was excised using $10 \%$ bleach-sterilized razor blades to ensure the mass of ingested food was excluded from subsequent body mass measurements. Individuals were then desiccated in an oven at $65^{\circ} \mathrm{C}$ to obtain total dry weight $(\mathrm{g})$, which

111 included a previously measured cup weight. Cup weight was subtracted from this value to obtain 112 the dry weight of each individual.

$113 \quad 2.3$ Statistical analyses The Ingestion Rate (IR) of each individual was measured using both pre- and postexperiment algal cell counts, adjusted for controls, as: 


$$
I R=\frac{\left[\left(E_{0}-E_{t}\right)-\left(C_{0}-C_{t}\right)\right]}{t}
$$

where $E_{0}$ and $E_{t}$ represent experimental algal cell concentrations at times 0 and $t$, respectively, $C_{0}$ and $C_{t}$ represent control algal cell concentrations at times 0 and $t$, and $t$ is experimental duration (1 hour). $C_{0}-C_{t}$ was included to adjust temporal changes in algal concentration due to algal growth or sedimentation in controls. Pre- and post-experiment algal concentrations were also used to determine the Clearance Rate (CR) of each individual as:

$$
\mathrm{CR}=\mathrm{V} \frac{\left[\ln \left(\mathrm{E}_{0} / \mathrm{E}_{\mathrm{t}}\right)-\ln \left(\mathrm{C}_{0} / \mathrm{C}_{\mathrm{t}}\right)\right]}{\mathrm{t}}
$$

where $V$ represents the volume of suspension. As with IR, a correction factor was included in CR to account for changes in control tanks where no animals were present (Coughlan 1969). Four of six calculated IR and CR values for $C$. intestinalis at the highest algal concentration (133084 cells $/ \mathrm{mL}$ ) were negative, possibly owing to a combination of sinking algal cells and/or less active animal feeding. Consequently, we removed this algal density from analysis for both species. Seven other negative values for IR and CR were also found for $C$. intestinalis and subsequently discarded when performing analysis. The reason for this problem is not clear, as we attempted to minimize disturbance and stress on animals prior to all feeding trails. We conducted two three-way ANOVA tests with the factors species, animal mass, food density, and their interactions to determine which factors affected IR and CR. Statistical analyses were performed in R-3.5.0 (R Core Team 2018) and RStudio 1.1.447 (RStudio Team 2016). Animal functional response to varying food concentration was modeled using the FRAIR package in R-3.5.0 (Pritchard 2017). As food was not replaced after consumption, Rogers' random predator equation was used to describe the type II functional response of $C$. intestinalis (Barrios-O’Neill et al. 2014, Rogers 1972): 


$$
N_{e}=N_{o}\left(1-\exp \left(a\left(N_{e} h-T\right)\right)\right)
$$

139

where $N_{e}$ is the number of food items consumed, $N_{0}$ is the initial concentration of algal cells, $a$ is attack rate, $h$ is handling time, and $T$ is experimental duration. As the ingestion rate of $C$. robusta generally increased linearly with increasing food concentration, a type I fit was applied to the consumption data (FRAIR; Pritchard 2017):

$$
N_{e}=N_{o}(a T)
$$

These models were then non-parametrically bootstrapped $(n=2000)$ to generate $95 \%$ confidence intervals for the functional response curves.

$$
\text { Relative Impact Potential (RIP; Dick et al. 2017) was calculated for co-occurring }
$$
ascidians using relative field abundance data from Brittany, France. For each instance in which the species co-occurred (130 in total; Bouchemousse et al., unpublished data, see Bouchemousse et al. (2017) for the sampling protocol) we obtained the ratio of relative abundance (A; measured as Ind. $/ \mathrm{m}^{2}$ ) of C. robusta to C. intestinalis. We then randomly drew (from between three and six measures per species) an IR for the invader and another for the native species. Relative Impact Potential (RIP) was then estimated as the product of a randomly drawn A (from 130 cooccurrence cases) and a randomly drawn IR ratio (invader IR divided by native IR) for that food concentration. Results were bootstrapped 10000 times incorporating different combinations of A and IR. Similar calculations were repeated for each food concentration. In Dick et al.'s (2017) original formulation of RIP, abundance was measured directly and utilized maximum feeding rate $(1 / h)$ from functional responses. Any combination of A and IR that yields a RIP $>1$ indicates a greater relative impact by the non-native species, while those $<1$ indicate greater impact by the native species. In this paper, we utilize individual IRs at different food concentrations to estimate feeding rather than maximum feeding rate. 
162

163

164

165

166

167

168

169

170

171

172

173

174

175

176

177

178

179

180

181

182

\section{Results}

C. robusta individuals tended to be slightly larger than co-occurring $C$. intestinalis and also exhibited greater dispersion in dry mass (Fig. 1). However, mass was not a significant factor contributing to differences in ingestion rates $\left(\mathrm{F}_{1,51}=0.07, \mathrm{P}=0.7920\right)$, although its effect on clearance rate was considerable $\left(\mathrm{F}_{1,51}=8.76, \mathrm{P}=0.0047\right)$.

C. robusta had higher ingestion rates $\left(\mathrm{F}_{1,51}=6.9, \mathrm{P}=0.011\right)$ and clearance rates $\left(\mathrm{F}_{1,51}=\right.$ 19.2, $\mathrm{P}<0.001$ ) than C. intestinalis (Fig. 2). Food concentration was a strong predictor of ingestion rates $\left(\mathrm{F}_{1,51}=73.4, \mathrm{P}<0.001\right)$, though it had no effect on clearance rate $\left(\mathrm{F}_{1,51}=0.9, \mathrm{P}=\right.$ $0.353)$. Ingestion rate was also affected by a species $\times$ food concentration interaction, with $C$.

robusta increasing at a faster rate with increasing food level (Figs. 2, 3). A similar pattern was not apparent with species clearance rates $\left(\mathrm{F}_{1,51}=2.1, \mathrm{P}=0.154\right)$. Ingestion rate $\left(\mathrm{F}_{1,51}=6.7, \mathrm{P}=\right.$ $0.013)$ and clearance rate $\left(\mathrm{F}_{1,51}=4.5, \mathrm{P}=0.038\right)$ also exhibited a significant $\operatorname{mass} \times$ food concentration interaction.

Functional responses of the two ascidian species differed substantially. The invader, $C$.

robusta, exhibited a more profound increase in ingestion rate with increasing food level, consistent with a type I functional response (Fig. 3). The native species, C. intestinalis, displayed an asymptotic functional response to increasing food level, conforming to a type II curve. Modelling with the FRAIR package in R-3.5.0 allowed for the determination of feeding parameters for both species. Ingestion by C. intestinalis was best described using the Rogers' random predator equation for type II functional responses, resulting in an attack rate $a=0.124$ (P $<0.001)$ and handling time $h=8.294 \times 10^{-5}(\mathrm{P}<0.001)$. In contrast, C. robusta had a 
183 substantially higher attack rate $(a=0.196, \mathrm{P}<0.001)$ and a negligible handling time,

184 characteristic of type I functional responses.

Field abundance data in Brittany, France, where the species co-occur illustrate that $C$.

intestinalis occurs more commonly than C. robusta. In over 361 quadrats studied, there were 188

instances where only the former species was present, three cases where only C. robusta occurred, 130 cases where species co-occurred, and 40 cases where neither species was found. When the species co-occurred, bootstrapped seasonal abundance data revealed dominance by the introduced species (mean ratio A of 1.31 of C. robusta to C. intestinalis). IR ratios ranged 191 between 1.27 and 7.92 (mean 4.46), indicating higher feeding rates by C. robusta. RIP values 192 (mean 5.77) indicate that C. robusta typically had a much greater relative impact. RIP values 193 were generally higher at higher food concentrations, with mean bootstrapped values of 1.89, 7.10, $1941.61,10.13,6.62$ and 7.25 across food concentrations of 1508, 3380, 5900, 12873, 29539 and 19551616 cells $/ \mathrm{mL}$, respectively. Most of C. robusta's greater feeding impact was attributable to its 196 higher IR, though higher abundance was also important.

\section{Discussion}

Ascidians have experienced many biological invasions and concomitant range expansions 200 in recent decades (e.g. Gittenberger 2007; Lambert 2007, 2009; Ruis et al. 2012; Ordóñez et al. 201 2013; Zhan et al. 2015; Bullard and Carmen 2016; Simkanin et al. 2016; Nydam et al. 2017). 202 The English Channel is no exception, with numerous reports of introduced ascidians including 203 Botrylloides violaceus, B. diegensis, Aplidium glabrum, Diplosoma listerianum, Molgula 204 complanata, Corella eumyota, Perophora japonica, Styela clava, Didemnum vexillum, 205 Asterocarpa humilis and Ciona robusta established on both sides of the channel (Gittenberger 

2007; Zhan et al. 2010; Minchin et al. 2013; Bishop et al. 2015). C. robusta was long confused with $C$. intestinalis, though they are genetically and morphologically distinct and seemingly reproductively isolated (Zhan et al. 2010; Sato et al. 2012; Brunetti et al. 2015; Bouchemousse et al. 2016a). As the species co-occur on both sides of the English Channel it is possible that they compete for settlement substrates, though Bouchemousse et al. (2017) reported highly variable settlement and suggested environmental variation modulated competition. It is also possible the species compete for food at times. Our study revealed significant feeding rate differences

213 between the species, with introduced C. robusta exhibiting higher ingestion rates and clearance 214 rates than native C. intestinalis (Fig. 2a,b). Differences in ingestion rate were more pronounced 215 as food concentration increased, suggesting high food levels in nature could favor the introduced 216 species.

Functional responses of $C$. robusta and $C$. intestinalis also differed, conforming to type I and II curves, respectively (Fig. 3). Type II curves and higher FR of the introduced species are consistent with an array of aquatic and terrestrial invertebrates, fishes and with plants (Dick et al. 2017). The greater FR of C. robusta was largely responsible for its higher RIP scores. Thus,

221 when the species co-occur, C. robusta should have a greater impact on algal foods than $C$.

222 intestinalis. However, co-occurrence of the species in nature is less common (130 occurrences) 223 than instances where C. intestinalis (188 cases) occurs alone, thus the regional impact of the 224 invader will be muted by its more confined distribution. We expect that impact exerted by $C$. 225 robusta would expand commensurate with the extension of its distribution. Clearance rates have been well-studied in ascidians (see Jacobi et al. (2018) and 227 references cited therein). The absence of an apparent asymptote in feeding rate in C. robusta 228 (Fig. 3 dashed line) was surprising given the broad range of food concentrations provided to 
study animals. However, Pascoe et al. (2007) observed that $C$. intestinalis exhibited a strong positive relationship between ingestion rate and food concentration up to $10^{6}$ cells $/ \mathrm{mL}$ of Isochrysis galbana. Armsworthy et al. (2001) also noted that IR increased linearly with food concentration in the ascidian Halocynthia pyriformis. Pascoe et al. (2007) also revealed that CR was maximal around $5 \times 10^{3}$ cells $/ \mathrm{mL}$, whereas we did not observe a clear maximum for either species tested (Fig. 2b). Typically with filter-feeders, a maximum algal concentration is reached (i.e. Incipient Limiting Level) beyond which IR is constant and CR declines exponentially (e.g. Robbins 1983; Petersen and Riisgård 1992; Sigsgaard et al. 2003; Petersen 2007). At high suspended particulate load, a reduction in IR associated with satiation (Pascoe et al. 2007) could be active rejection (ie. squirting; Robbins 1984; Petersen 2007) or a reduction in lateral cilia beat frequency (Petersen 2007). It is important to note that we also did not observe a decline in CR at very low food levels, which some authors attributed to reduced cilia beating in the branchial basket (Petersen et al. 1999).

Our study had some unexpected IR, and hence CR, results. For example, from an initial 39 total observations, a majority of IR and CR values for $C$. intestinalis at the highest food concentration were negative and thus removed. We likewise removed high food concentration feeding results for $C$. robusta even though this species was not plagued by this issue. A number of other studies have observed a reduction in clearance rate with increasing food concentration (Petersen and Riisgård 1992; Petersen et al. 1999). At high food concentrations, the gut reaches an intake threshold above which the clearance rate is reduced as a form of protection against gut saturation (see Petersen and Riisgård 1992; Petersen et al. 1999; Petersen 2007). Petersen (2007) recommended an acclimation period of 20-140 min prior to measuring clearance rates. While our experiment did not incorporate a formal adjustment period, we commenced experiments only 
after animals appeared robust with seemingly normal feeding behaviour. Seven of the 39 trials conducted also yielded negative IR and CR results, though the problem was limited to $C$. intestinalis predominantly at the three lowest food concentrations. These cases were removed prior to statistical analysis, though the reason for the aberrant results remains unclear. numerical reponses such as abundance, can rapidly inform actual or potential ecological impacts of invasions (Dick et al. 2017a,b). Here, with our ascidian example, these methods are congruous with field patterns of invasions and ecological impact, including competition and species displacement. We encourage further development of these metrics across taxonomic and trophic 261 groups, and incorporation of context-dependencies, such as temperature change with climate 262 change (Dick et al. 2017b). This will allow invasion ecology to become truly predictive, with opportunities to focus limited resources on the most harmful actual and potential invaders.

\section{Acknowledgements}

This was supported by an NSERC undergraduate fellowship to TH, while HJM was supported by an NSERC Discovery grant and by a Canada Research Chair. We appreciate modeling assistance from Ryan Scott. We also thank the Centre de Ressources Biologiques Marines

269 (CRBM) for algae culture and aquarium assistance, and the Service Mer \& Observation (SMO)

270 for diving and collection assistance, both of the Roscoff Biological Station, France. Jérôme

271 Coudret, Thierry Comtet, and Dominique Marie (Roscoff Biological Station) were also of great

272 help for technical and methodological assistance. 
Allen JD, McIntyre PB, Smith SDP, Halpern BS, Boyer GL, Buchsbaum A, Burton GA, Campbell LM, Chadderton WL, Ciborowski JJH, Doran PJ, Eder T, Infante DM, Johnson LB, Joseph CA, Marino AL, Prusevich A, Read JG, Rose JB, Rutherford ES, Sowa SP, Steinman AD (2013) Joint analysis of stressors and ecosystem services to enhance restoration effectiveness. Proc Natl Acad Sci (USA) 110:372-377

Armsworthy SL, MacDonald BA, Ward JE (2001) Feeding activity, absorption efficiency and suspension feeding processes in the ascidian, Holocynthia pyriformis (Stolidobranchia: Ascidiacea): responses to variations in diet quantity and quality. J Exp Mar Biol Ecol 260:4169

Arthington AH, Dulvy NK, Gladstone W, Winfield IJ (2016) Fish conservation in freshwater and marine realms: status, threats and management. Aquat Conserv: Mar Freshwat Ecosyst

Barrios-O’Neill D, Dick JTA, Emmerson MC, Ricciardi A, MacIsaac HJ, Alexander ME, Bovy HC (2014) Fortune favours the bold: a higher predator reduces the impact of a native but not an invasive intermediate predator. J Anim Ecol 83:693-701

Bendif EM, Probert I, Schroeder DC, de Vargas C (2013) On the description of Tisochrysis lutea gen. nov. sp. nov. and Isochrysis nuda sp. nov. in the Isochrysidales, and the transfer of Dicrateria to the Prymnesiales (Haptophyta). J Appl Phycol 25:1763-1776.

Bishop JDD, Wood CA, Yunnie ALE, Griffiths CA (2015) Unheralded arrivals: non-native sessile invertebrates in marinas on the English coast. Aquat Invas 10:249-264

Bock DG, Zhan A, Lejeusne CL, MacIsaac HJ, Cristescu ME (2011) Looking at both sides of the invasion: patterns of colonization in the violet tunicate Botrylloides violaceus. Mol Ecol 
Bouchemousse, S (2015) Dynamique éco-évolutive de deux ascidies congénériques et interfertiles, l'une indigène et l'autre introduite, dans leur zone de sympatrie. Biodiversité. Université Pierre et Marie Curie - Paris VI.

Bouchemousse S, Lévêque L, Dubois G, Viard F (2016a) Co-occurrence and reproductive synchrony does not ensure hybridization between an alien tunicate and its infertile native congener. Evol Ecol 30:69-87

Bouchemousse S, Bishop JDD, Viard F (2016b) Contrasting global genetic patterns in two biologically similar, widespread and invasive Ciona species (Tunicata, Ascidiacea). Sci Reports 6:24875. DOI:10.1038/srep24875

Bouchemousse S, Lévêque L, Viard F (2017) Do settlement dynamics influence competitive interactions between an alien tunicate and its native congener? Ecol Evolut 7:200-213

Brunetti R, Gissi C, Pennati R, Caicci F, Gasparini F, Manni L (2015) Morphological evidence that the molecularly determined Ciona intestinalis type A and type B are different species: Ciona robusta and Ciona intestinalis. J Zool Syst Evol Res 53:186-193

Bullard SG, Carman MR (2016) Introduction to the proceedings of the 5th International Invasive Sea Squirt Conference 7:1-3

Clavero M, García-Berthou E (2005) Invasive species are a leading cause of animal extinctions. Trends Ecol Evol 20:110

Dick JTA, Alexander ME, Jeschke JM, Ricciardi A, MacIsaac HJ, Robinson TB, Kumschick S, Weyl OLF, Dunn AM, Hatcher MJ, Paterson RA, Farnsworth KD, Richardson DM (2014) Advancing impact prediction and hypothesis testing in invasion ecology using a comparative functional response approach. Biol Invas 16:735-753 
Dick JTA, Laverty C, Lennon JJ, Barrios-O'Neill D, Mensink P, Britton JR, Medoc V, Boets P, Alexander ME, Taylor NG, Dunn AM, Hatcher MJ, Rosewarne PJ, Crookes S, MacIsaac HJ, Xu M, Ricciardi A, Wasserman RJ, Ellender BR, Lucy FE, Banks PB, Dodd JA, MacNeil C, Penk MR, Aldridge DC, Caffrey JM (2017a) Invader Relative Impact Potential: a new metric to understand and predict the ecological impacts of existing, emerging and future invasive alien species. J Applied Ecol 54: 1259-1267

Dick JTA, Alexander ME, Ricciardi A, Laverty C, Downey PO, Xu M, Jeschke JM, Saul W-C, Hill MP, Wasserman RJ, Barrios-O’Neill D, Weyl OLF, Shaw RH (2017b) Functional responses can unify invasion ecology. Biol Invas 19:1667-1672

Gittenberger A (2007) Recent population expansions of non-native ascidians in the Netherlands. J Exp Mar Biol Ecol 342:122-126

Jacobi Y, Yahel G, Shenkar N (2018) Efficient filtration of micron and submicron particles by ascidians from oligotrophic waters. Limn Oceanogr 63:S267-S279

Jeschke JN, Kopp M, Tollrian R (2004) Consumer-food systems: why type I functional responses are exclusive to filter feeders. Biol Rev 79:337-349

Kumschick S, Gaertner M, Vilà M, Essl F, Jeschke JM, Pyšek P, Bacher S, Blackburn TM, Dick JTA, Evans T, Hulme PE, Kühn I, Mrugała A, Pergl J, Rabitsch W, Ricciardi A, Richardson DM, Sendek A, Winter, M (2015) Ecological impacts of alien species: quantification, scope, caveats and recommendations. Bioscience 65:55-63

Lambert, G. 2001. A global overview of ascidian introductions and their possible impact on the endemic fauna. In: Sawada, H., Yokosawa, H. and Lambert, C. C. (ed.), The Biology of Ascidians. Tokyo, Springer-Verlag, pp. 249-257. 
342 Lambert, G. 2007. Invasive sea squirts: A growing global problem. J. Exp. Mar. Biol. Ecol. $343 \quad 342: 3-4$

344 Lambert, G. 2009. Adventures of a sea squirt sleuth: unraveling the identity of Didemnum 345 vexillum, a global ascidian invader. Aquatic Invasions 4:5-28.

346 Minchin D, Cook EJ, Clark PF (2013) Alien species in British brackish and marine waters. $347 \quad$ Aquat Invas 8:3-19

348 Nydam ML, Giesbrecht KB, Stephenson EE (2017) Origin and dispersal history of two colonial 349 ascidian clades in the Botryllus schlosseri species complex. PloS ONE e0169944. DOI:

$350 \quad$ 10.1371/journal.pone.0169944

351 Ordóñez V, Pascual M, Ruis M, Turon X (2013) Mixed but not admixed: a spatial analysis of 352 genetic variation of an invasive ascidian on natural and artificial substrates. Mar Biol $353 \quad 160: 1645-1660$

354 Pascoe PL, Parry HE, Hawkins AJS (2007) Dynamic filter-feeding responses in fouling organisms. Aquat Biol 1:177-185

Petersen JK, Riisgård HU (1992) Filtration capacity of the ascidian Ciona intestinalis and its grazing impact in a shallow fjord. Mar Ecol Prog Ser 88:9-17

358 Petersen JK, Mayer S, Knudsen MÅ (1999) Beat frequency of cilia in the branchial basket of the ascidian Ciona intestinalis in relation to temperature and algal food concentration. Mar Biol $133: 185-192$

361 Petersen, J. K. 2007. Ascidian suspension feeding. J. Exp. Mar. Biol. Ecol. 342: 127-137.

362 Petersen JK, Maar M, Møhlenberg F, Larsen JEN (2012) Benthic grazing impact: coupling and uncoupling in relation to physical forcing. Mar Ecol Prog Ser 463:127-139 
364 Pritchard D (2017) frair: Tools for Functional Response Analysis. R package version 0.5.100. https://CRAN.R-project.org/package=frair

R Core Team (2013). R: A language and environment for statistical computing. R Foundation for Statistical Computing, Vienna, Austria. URL http:/www.R-project.org/.

Ricciardi A. 2006. Are modern biological invasions an unprecedented form of global change? Con Biol 21:329-336

Robbins IJ (1983) The effects of body size, temperature, and suspension density on the filtration and ingestion of inorganic particulate suspensions by ascidians. J Exp Mar Biol Ecol 70:65-

Rogers D (1972) Random search and insect population models. J Anim Ecol 41:369-383

Ruis M, Turon X, Ordóñez V, Pascual M (2012) Tracking invasion histories in the sea: facing complex scenarios using multilocus data. PLoS ONE 7(4) e35815 doi:10.1371/journal.pone.0035815

RStudio Team (2015). RStudio: Integrated Development for R. RStudio, Inc., Boston, MA http://www.rstudio.com

Sato A, Satoh N, Bishop JDD (2012) Field identification of 'types' A and B of the ascidian Ciona intestinalis in a region of sympatry. Mar Biol 159:1611-1619

381 Sigsgaard SJ, Petersen JK, Iversen JJL (2003) Relationship between specific dynamic action and food quality in the solitary ascidian Ciona intestinalis. Mar Biol 143:1143-1149

383 Simkanin C, Fofonoff PW, Larson K, Lambert G, Dijkstra JA, Ruiz GM (2016) Spatial and 384 temporal dynamics of ascidian invasions in the continental United States and Alaska. Mar Biol 163: 1-16 
386 Sorte CJB, Williams SL, Zerebecki RA (2010) Ocean warming increases threat of invasive $387 \quad$ species in a marine fouling community. Ecology 91:2198-2204

388 Zhan A, MacIsaac HJ, Cristescu ME (2010) Invasion genetics of the Ciona intestinalis species 389 complex: from regional endemism to global homogeneity. Mol Ecol 19:4678-4694

390 Zhan A, Briski E, Bock DG, Ghabooli S, MacIsaac HJ (2015) Ascidians as models for studying 391 invasion success. Mar Biol 162:2449-2470 
Figure Legends

394 Figure 1. Ingestion rate (a) and clearance rate (b) of native (filled circles) and invasive (open circles) Ciona individuals as a function of animal dry mass. Note the log scale for both graphs.

397 Figure 2. Ingestion rate (a) and clearance rate (b) of Ciona individuals as a function of Isochrysis affinis galbana concentration. Overlapping points in b have been slightly offset to the right for clarity. Note the log scale for ingestion rate (a).

400 Figure 3. Fitted functional responses of native (solid line) and introduced (dashed) Ciona (with 95\% CI bands). C. robusta statistically conforms to a type I functional response, while $C$. intestinalis conforms to a type II response. 
Hoxha et al. 20

$404 \quad$ Figure 1

405

406

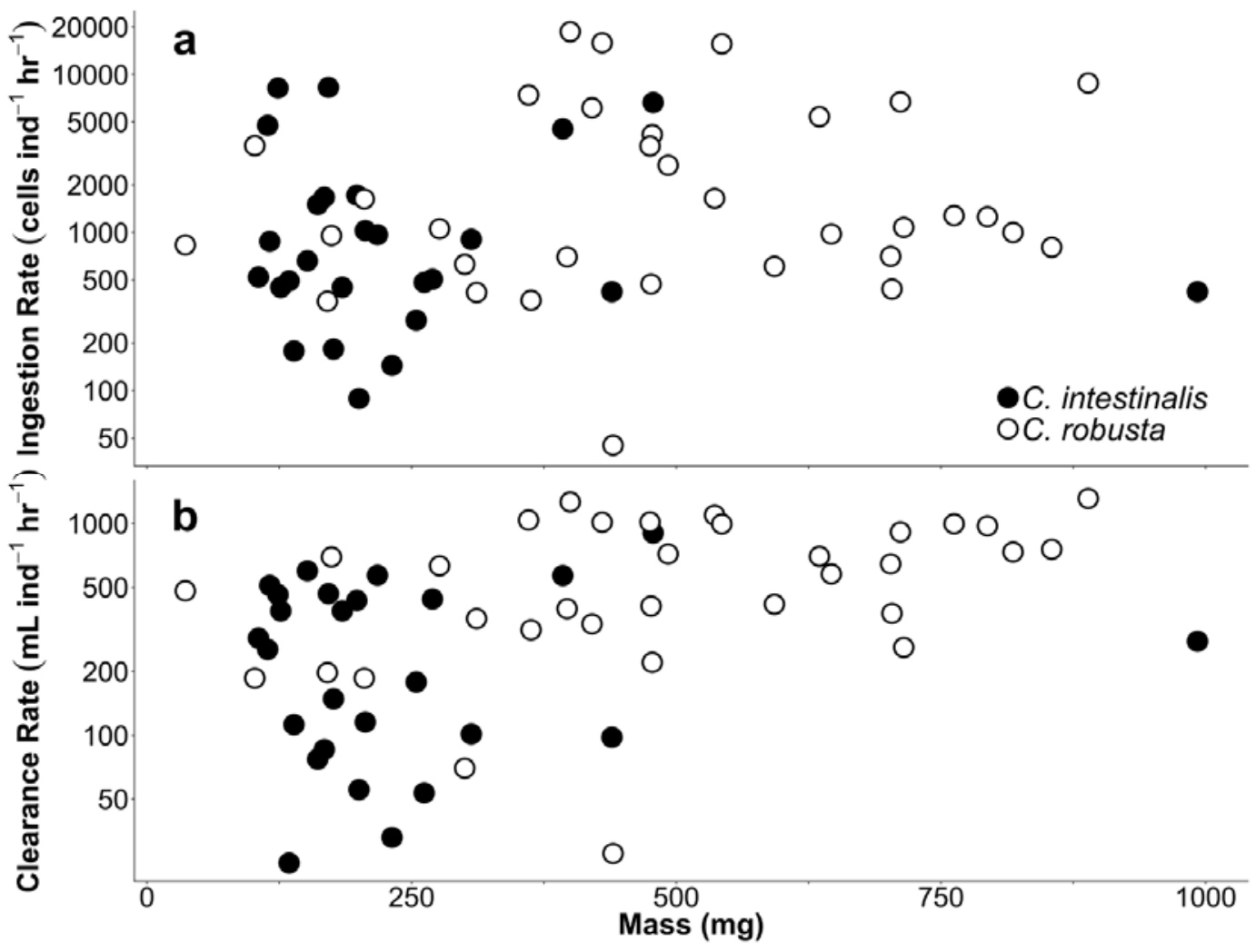

407 
408 Figure 2

409

410

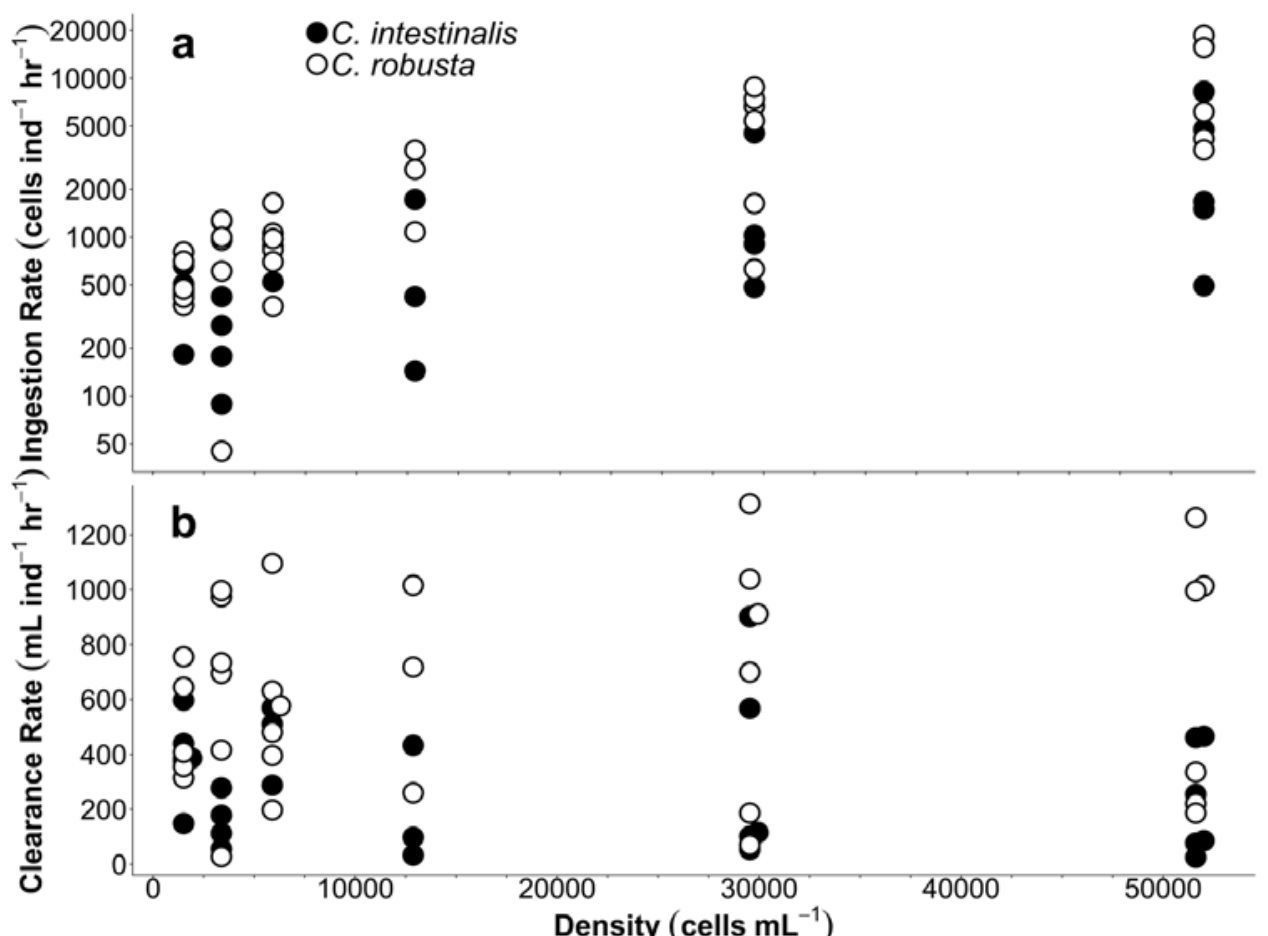


Hoxha et al. 22

412 Figure 3

413

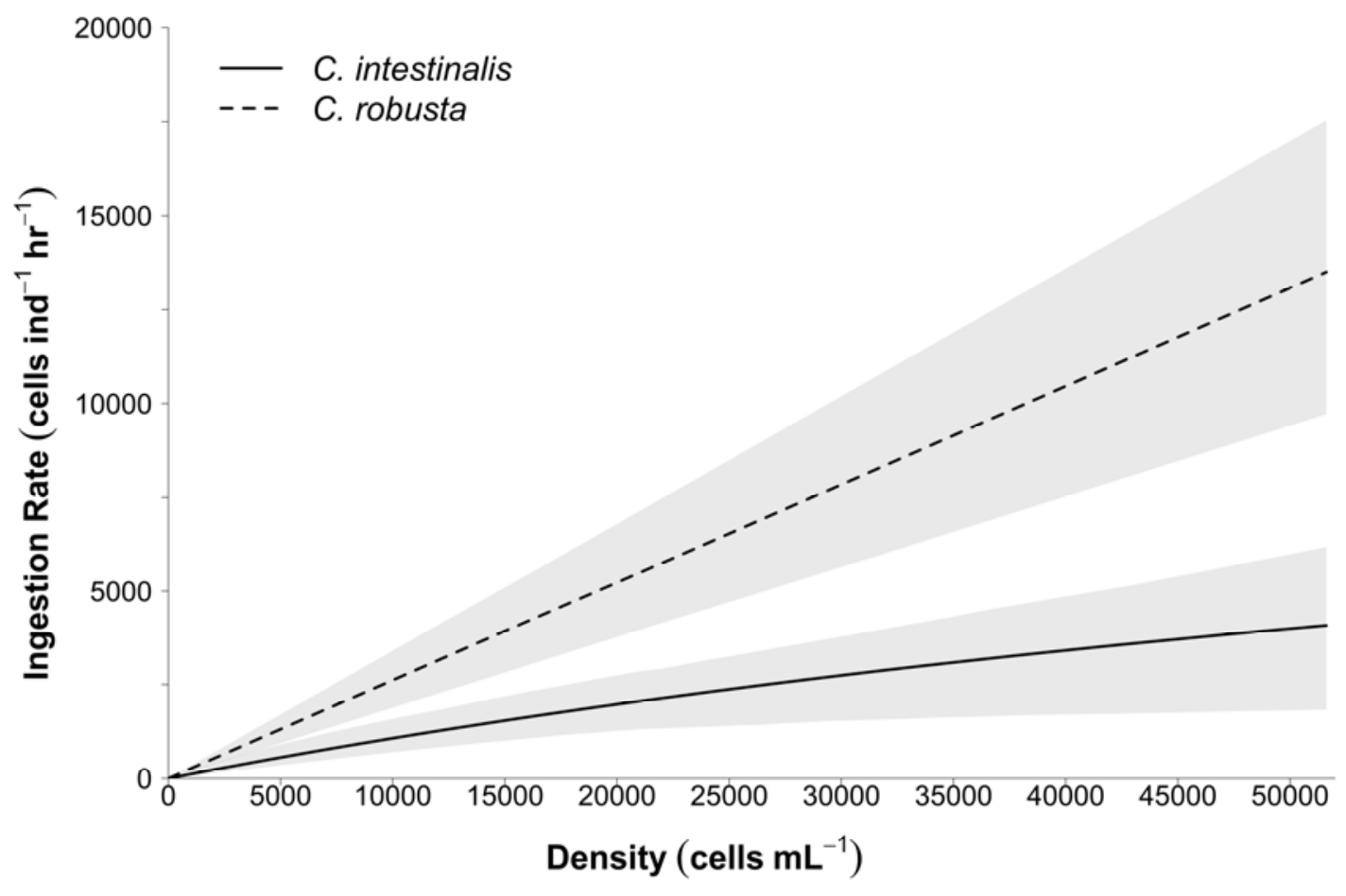

414 